\title{
Interaction of marine ice-sheet instabilities in two drainage basins: simple scaling of geometry and transition time
}

\author{
J. Feldmann ${ }^{1,2}$ and A. Levermann ${ }^{1,2}$ \\ ${ }^{1}$ Potsdam Institute for Climate Impact Research (PIK), Potsdam, Germany \\ ${ }^{2}$ Institute of Physics, University of Potsdam, Potsdam, Germany \\ Correspondence to: J. Feldmann (johannes.feldmann@pik-potsdam.de)
}

Received: 15 August 2014 - Published in The Cryosphere Discuss.: 12 September 2014

Revised: 13 March 2015 - Accepted: 19 March 2015 - Published: 2 April 2015

\begin{abstract}
The initiation of a marine ice-sheet instability (MISI) is generally discussed from the ocean side of the ice sheet. It has been shown that the reduction in ice-shelf buttressing and softening of the coastal ice can destabilize a marine ice sheet if the bedrock is sloping upward towards the ocean. Using a conceptional flow-line geometry, we investigate the possibility of whether a MISI can be triggered from the direction of the ice divide as opposed to coastal forcing and explore the interaction between connected basins. We find that the initiation of a MISI in one basin can induce a destabilization in the other. The underlying mechanism of basin interaction is based on dynamic thinning and a consecutive motion of the ice divide which induces a thinning in the adjacent basin and a successive initiation of the instability. Our simplified and symmetric topographic setup allows scaling both the geometry and the transition time between both instabilities. We find that the ice profile follows a universal shape that is scaled with the horizontal extent of the ice sheet and that the same exponent of $1 / 2$ applies for the scaling relation between central surface elevation and horizontal extent as in the pure shallow ice approximation (Vialov profile). Altering the central bed elevation, we find that the extent of grounding-line retreat in one basin determines the degree of interaction with the other. Different scenarios of basin interaction are discussed based on our modeling results as well as on a conceptual flux-balance analysis. We conclude that for the three-dimensional case, the possibility of drainage basin interaction on timescales on the order of $1 \mathrm{kyr}$ or larger cannot be excluded and hence needs further investigation.
\end{abstract}

\section{Introduction}

Recent studies that investigate the future evolution of the West Antarctic Ice Sheet (WAIS) by basin-scale numerical modeling suggest that a destabilization of parts of it is under way (Katz and Worster, 2010; Favier et al., 2014; Joughin et al., 2014). The bed geometry of the WAIS (Figs. 1 and 2) makes it susceptible to a marine ice-sheet instability (MISI), proposed several decades ago (Mercer, 1978; Schoof, 2007a; Joughin and Alley, 2011). Pine Island Glacier (PIG) and Thwaites Glacier (TG) are two major tributaries of the WAIS, are most likely out-of-balance and exhibit the highest singleglacier mass loss in Antarctica (Rignot et al., 2008; Medley et al., 2014). Among other smaller glaciers in the Amundsen Sea sector they show a grounding-line retreat on retrograde (inland down-sloping) bed sections (Fig. 2) that reach deep into the interior of their basins (Vaughan et al., 2006; Tinto and Bell, 2011). The lack of substantial bed obstacles along these sections indicates that observed rapid changes, including grounding-line retreat, ice acceleration and thinning (Shepherd et al., 2002; Pritchard et al., 2012; Park et al., 2013; Mouginot et al., 2014), and thus destabilization are likely to continue (Rignot and Mouginot, 2014). The changes are attributed to increased sub-ice-shelf melting that is driven by relatively warm circumpolar deep water reaching towards the glaciers' grounding lines (Walker et al., 2007; Jacobs et al., 2011; Rignot et al., 2013). PIG and TG basins contain enough ice to raise global sea level by $\sim 24$ and $\sim 59 \mathrm{~cm}$, respectively (Holt et al., 2006; Vaughan et al., 2006).

It can be presumed that a full drainage of one of these basins or of both basins would imply an even larger sealevel contribution due to additional ice supply from other 


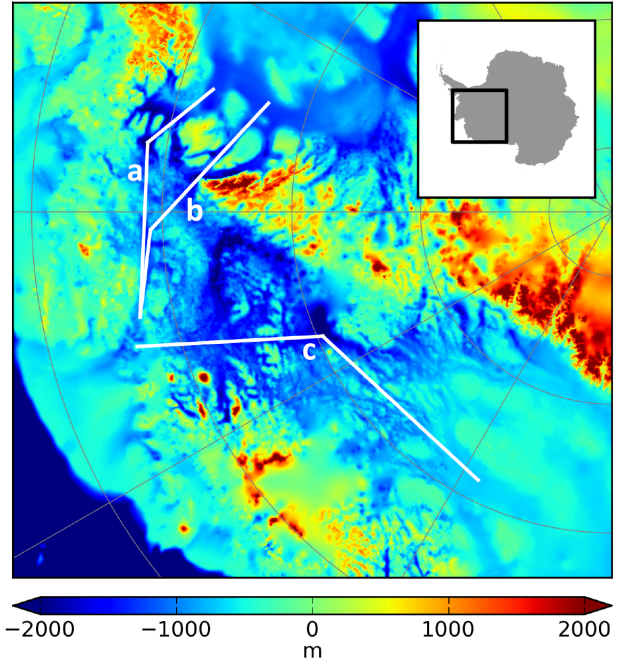

Figure 1. Topographic map of the bedrock underlying the Antarctic Ice Sheet. Each of the transects (white lines) connects two major drainage basins of the WAIS. The bed topography and the ice profile along transects (a), (b) and (c) are shown in the corresponding panels of Fig. 2.

connected basins (Stuiver et al., 1981; Holt et al., 2006). Multiple studies show that due to ice stream thinning, marginal (grounding line) retreat or changing accumulation patterns ice divides can indeed shift (Anandakrishnan et al., 1994; Cuffey and Clow, 1997; Nereson et al., 1998). Prominent examples are Siple Dome and two other inter-ice-stream ridges in West Antarctica whose ice divides have migrated in response to changed dynamics in their lateral ice streams (Nereson and Raymond, 2001). Numerical modeling of the response of the Antarctic Ice Sheet to extensive sub-ice-shelf melting (SeaRISE project, Bindschadler et al., 2013) showed the possibility of a collapse of the WAIS that implies the migration of ice divides and the eventual merging of several drainage basins in West Antarctica. However, in the SeaRISE experiments, the coastal forcing was applied to the whole Antarctic Ice Sheet, and hence all drainage basins where perturbed simultaneously. With this approach no statements can be made on the influence of a perturbed basin on a connected unperturbed basin.

Here we investigate how the ice dynamics in a drainage basin can be affected by changes originating from the direction of the ice divide as opposed to coastal forcing and analyze the interaction between connected basins. Using a flowline setup, we show that the initiation of a MISI in one basin leads to grounding-line retreat in a connected basin and can trigger its destabilization. First of all we describe our symmetric model setup and the set of experiments, designed to perturb a steady-state ice sheet. We then analyze the evolution of the relaxing ice sheet in response to the perturbation. Different scenarios of basin interaction are examined based on our results from modeling, as well as conceptually. A sim-

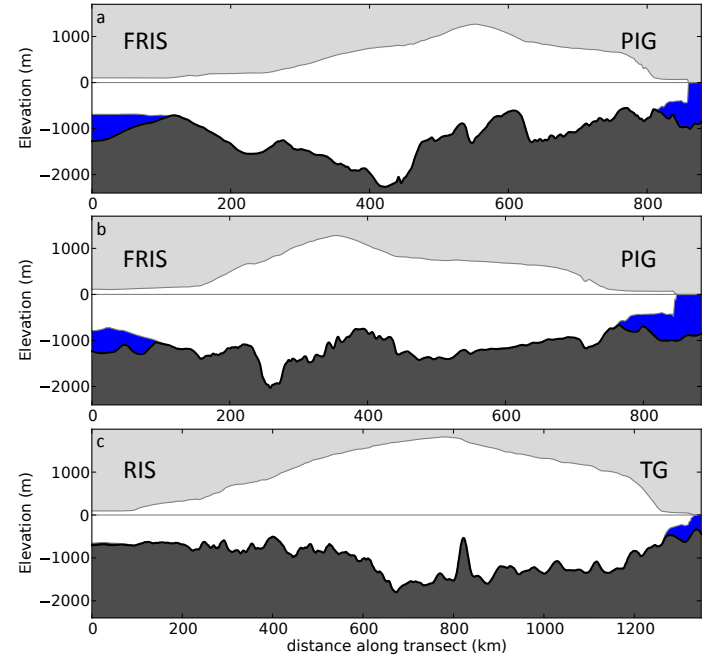

Figure 2. Cross-sections through the ice and the bed along the transects depicted in Fig. 1: bed topography (dark gray), ice sheet (white), ocean (blue). Both transects (a) and (b) connect the basins of Filchner-Ronne Ice Shelf (FRIS) and Pine Island Glacier (PIG). Transect (c) goes through the basins of Ross Ice Shelf (RIS) and Thwaites Glacier (TG).

ple scaling of the steady-state ice surface elevation as well as the transition time between the instabilities in both basins is proposed. Finally, we discuss the results and conclude.

\section{Model and experiments}

The model we use in our experiments is the Parallel Ice Sheet Model (PISM). It is an open-source, thermomechanically coupled, three-dimensional model (Bueler and Brown, 2009, http://www.pism-docs.org). PISM uses a superposition of the shallow ice and the shallow shelf approximations (SIA and SSA) of the stress balance to calculate ice velocities (Winkelmann et al., 2011). Since the SSA velocities are used as basal velocities for the grounded parts of the ice, a smooth transition of the velocity field between the grounded and floating regimes is ensured (Martin et al., 2011). The model used in this study is based on PISM version stable 0.5. The combination of (1) a linear interpolation of the grounding line with locally interpolated basal friction and (2) a modified driving-stress computation across the grounding line led to a significantly improved performance of PISM in the MISMIP3d model intercomparison (shown in Feldmann et al., 2014, compare to Pattyn et al., 2013).

For the perturbation experiments in the present study subice-shelf melt rates are parameterized following Beckmann and Goosse (2003); Martin et al. (2011). According to the parameterization the melt rates are proportional to the temperature difference between a prescribed value for the water in the sub-shelf cavity and the local pressure melting point of the ice. The basal melt rates are calculated not only for 

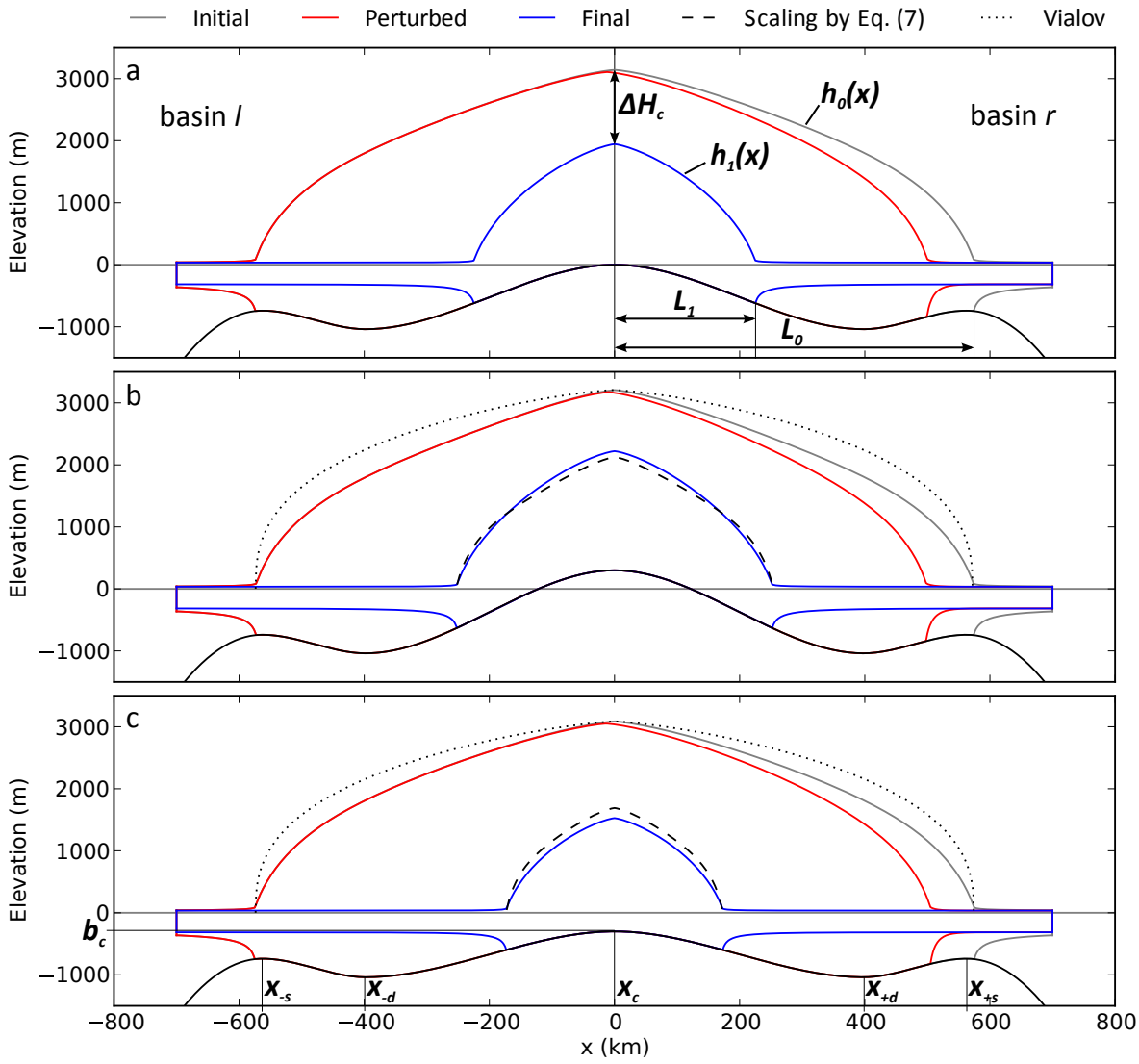

Figure 3. Ice-sheet profiles at three stages of simulation for three different values of central bed elevation (a) $b_{\mathrm{c}}=0 \mathrm{~m},(\mathbf{b}) b_{\mathrm{c}}=+300 \mathrm{~m}$ and (c) $b_{\mathrm{c}}=-300 \mathrm{~m}$. Panels (a) and (c) depict the notation used in the text.

the floating ice shelf but also for grounded grid cells with bed below sea level adjacent to a floating grid cell (coastal grid cells). Using a linear interpolation of the grounding-line position on a sub-grid (Gladstone et al., 2010) that yields an effective floating fraction for each grid cell (between 0 and 1, illustrated in Feldmann et al., 2014, Fig. 1) we scale the melt rate for each grid cell in the vicinity of the grounding line. Hence (reduced) ocean melting is also applied to coastal grid cells that are partially floating according to the sub-grid scheme. This caricature of a grounding zone allows us to force a grounding-line retreat in our flow-line setup, i.e., in the absence of buttressing, which would not be possible by melting solely under the ice shelf (Pattyn et al., 2006; Gagliardini et al., 2010; Gudmundsson, 2013). This kind of perturbation depicts a minimally invasive and very localized forcing. Other forcings, such as the modification of ice softness or basal friction, can also trigger grounding-line migration (Schoof, 2007a; Pattyn et al., 2013) but affect the ice sheet on a larger scale. Since the specific way in which the grounding-line retreat is triggered is not central to the mechanism described here, we chose the trigger that is changing least of the ice sheet and especially does not interfere with the rheology of the ice or the bedrock. The results obtained here are independent of the selected trigger mechanism (see Appendix A).

The computational domain of our setup stretches from -800 to $800 \mathrm{~km}$ in $x$ direction (flow direction). The bed geometry (Fig. 3, black line) is symmetric around $x_{\mathrm{c}}=0$ and is similar to a bed geometry introduced by Schoof (2007a), which was later used in MISMIP (Pattyn et al., 2012, hysteresis experiment EXP 3) and also used (modified) in other studies that conceptually investigate the stability of marine ice sheets (Goldberg et al., 2009; Gudmundsson et al., 2012). We use a piecewise cubic spline interpolation between the nodes $x_{\mathrm{c}}$ (location of the maximum of a central ridge), $x_{ \pm \mathrm{d}}=$ $\pm 398 \mathrm{~km}$ (location of the minimum of a bed depression) and $x_{ \pm \mathrm{s}}= \pm 562 \mathrm{~km}$ (location of a coastal sill). At each of these nodes a value for the bed elevation as well as the first derivative (equal to zero, since the nodes are locations of local extrema) are prescribed. On the oceanward side of the sill another node with a non-zero first derivative ensures the steep sloping of the bed. The bed section between $x_{ \pm \mathrm{d}}$ and $x_{ \pm \mathrm{s}}$ is down-sloping inland and hence referred to as retrograde section in the following. Given the symmetry, the domain can be divided into two drainage basins, mirroring each other ("basin l" for the left-hand side (LHS) of the domain, i.e., 


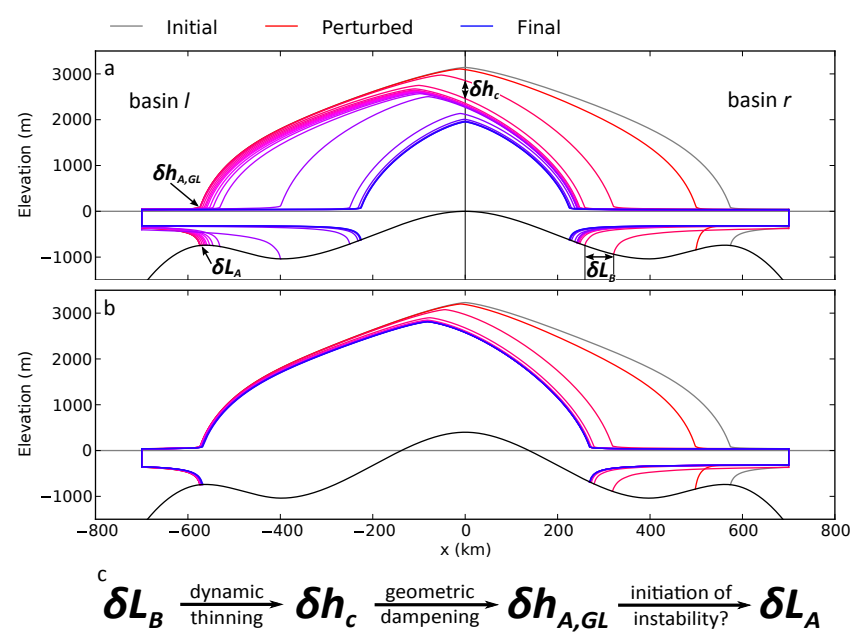

Figure 4. Profiles of the transient ice sheet between the end of perturbation (red), and the final steady state (blue) for two different values of central bed elevation (a) $b_{\mathrm{c}}=0 \mathrm{~m}$ (example of unstable scenario U, same as in Fig. 3a) and (b) $b_{\mathrm{c}}=+400 \mathrm{~m}$ (example of stable scenario $S$ ). The time interval between two consecutive profiles is $1 \mathrm{kyr}$. (c) explains the mechanism of basin interaction conceptually with the notation depicted in panel (a).

for $x<x_{\mathrm{c}}$, and "basin $\mathrm{r}$ " for the right-hand side (RHS) of the domain, i.e., for $x>x_{\mathrm{c}}$ ). Retrograde bed sections can be found in several connected drainage basins of the WAIS. To illustrate this, Fig. 2 shows cross-sections through the WAIS and its underlying bed topography along three transects, each of which connects two major drainage basins. The transects do not represent flow lines of the ice but exemplify the overdeepened geometry of parts of the basins. The average slope of PIG's retrograde bed section along transect a (that indeed goes through the main trough of the ice stream, Figs. 1 and 2a) is comparable to the maximum slope of the retrograde section in our setup (both are on the order of $-10^{-3}$ ).

The model is set up in a flow-line configuration with no lateral drag. However, to maintain the function of the model (i.e., the finite difference scheme), which is designed for two horizontal dimensions, we use three grid cells in $y$ direction and the lateral boundaries are periodic. Hence there is no variation in the cross-flow ( $y$ ) direction and the configuration is equivalent to the plane strain formulation of a flowline model. A boundary condition in $x$ direction is prescribed such that the calving front may not exceed $x= \pm 700 \mathrm{~km}$. Relevant parameter values as well as the non-linear friction law are the same as in the MISMIP3d experiments (Pattyn et al., 2013). The experiments are carried out on a fixed regular grid with a spatial resolution of $\Delta x=1 \mathrm{~km}$. Our modeled ice-sheet profile in steady state is compared to the semianalytical solution due to Schoof (2007a) in Appendix B.

Each of the simulations presented in this study is a set of three subsequent experiments, namely spin-up, perturbation and relaxation. The spin-up starts from an initial block of ice with a uniform upper surface elevation of $2000 \mathrm{~m}$. A symmetric ice-sheet-shelf system evolves with grounding lines located on the oceanward sides of the sill (Fig. 3). The system is run into equilibrium (the grounding-line positions are constant and the rate of relative volume change is smaller than $10^{-7} \mathrm{yr}^{-1}$ after $30 \mathrm{kyr}$ ). The steady-state ice sheet is then perturbed locally by applying melting beneath the ice shelf only in the RHS basin $\mathrm{r}(x>0)$. The parameters of the melt-rate equation are chosen such that the grounding line in basin $r$ is forced to retreat beyond the tip of the sill, being located on the retrograde section of the bed at the end of this $1.3 \mathrm{kyr}$ perturbation phase. In the third and last experiment, the subshelf melt rates are set to 0 again (i.e., the same boundary conditions as in the spin-up experiment apply) and the model is run for several $10 \mathrm{kyr}$, allowing the previously perturbed system to relax into a new steady state. This relaxation phase is analyzed in the results section.

This sequence of experiments is carried out for a range of different elevations of the central bed ridge, i.e., the bed section between the minima of the depressions, $x_{-\mathrm{d}}<x<x_{+\mathrm{d}}$ (compare Fig. 3a to c). To this end, the piecewise cubic spline interpolation that defines the bed geometry between $x_{\mathrm{c}}$ and $\pm x_{\mathrm{d}}$ is modified by prescribing a different value of $b_{\mathrm{c}}$ at node $x_{\mathrm{c}}$ for each individual setup. The interpolation remains otherwise unchanged; thus the bed sections for $x \leq x_{-\mathrm{d}}$ and $x \geq x_{+\mathrm{d}}$, respectively, are smoothly connected to the modified central bed section and are identical throughout all simulations. In the following text, individual simulations are abbreviated with "BC" followed by the value of the prescribed central bed elevation, e.g., BC+200 names the simulation using a value of $b_{\mathrm{c}}=+200 \mathrm{~m}$.

\section{Results}

Depending on the bed geometry, we investigate three qualitatively different scenarios of the time evolution of the ice sheet after cessation of the perturbation by basal ice-shelf melting in the RHS basin r. In all three scenarios the grounding line in basin $r$ continues to retreat after cessation of the forcing. It then migrates beyond the local minimum of the bed depression and stabilizes on the RHS flank of the central ridge.

The further evolution of the ice sheet depends on the bed topography. In the simulations with central bed elevation values ranging from $b_{\mathrm{c}}=-460$ to $+330 \mathrm{~m}$ the grounding line in the LHS basin 1 starts to retreat after a time of some kyr to several $10 \mathrm{kyr}$. The grounding line passes the tip of the local sill followed by an unstable retreat on the retrograde section of the bed. Similar to the previous retreat in basin $r$ the grounding line then stabilizes on the LHS flank of the central ridge. The resulting steady-state ice sheet is symmetric again and has shrunken significantly compared to its initial steady state. This scenario is referred to as "unstable" scenario $U$ afterwards (Figs. 3 and 4a). For the simulations 


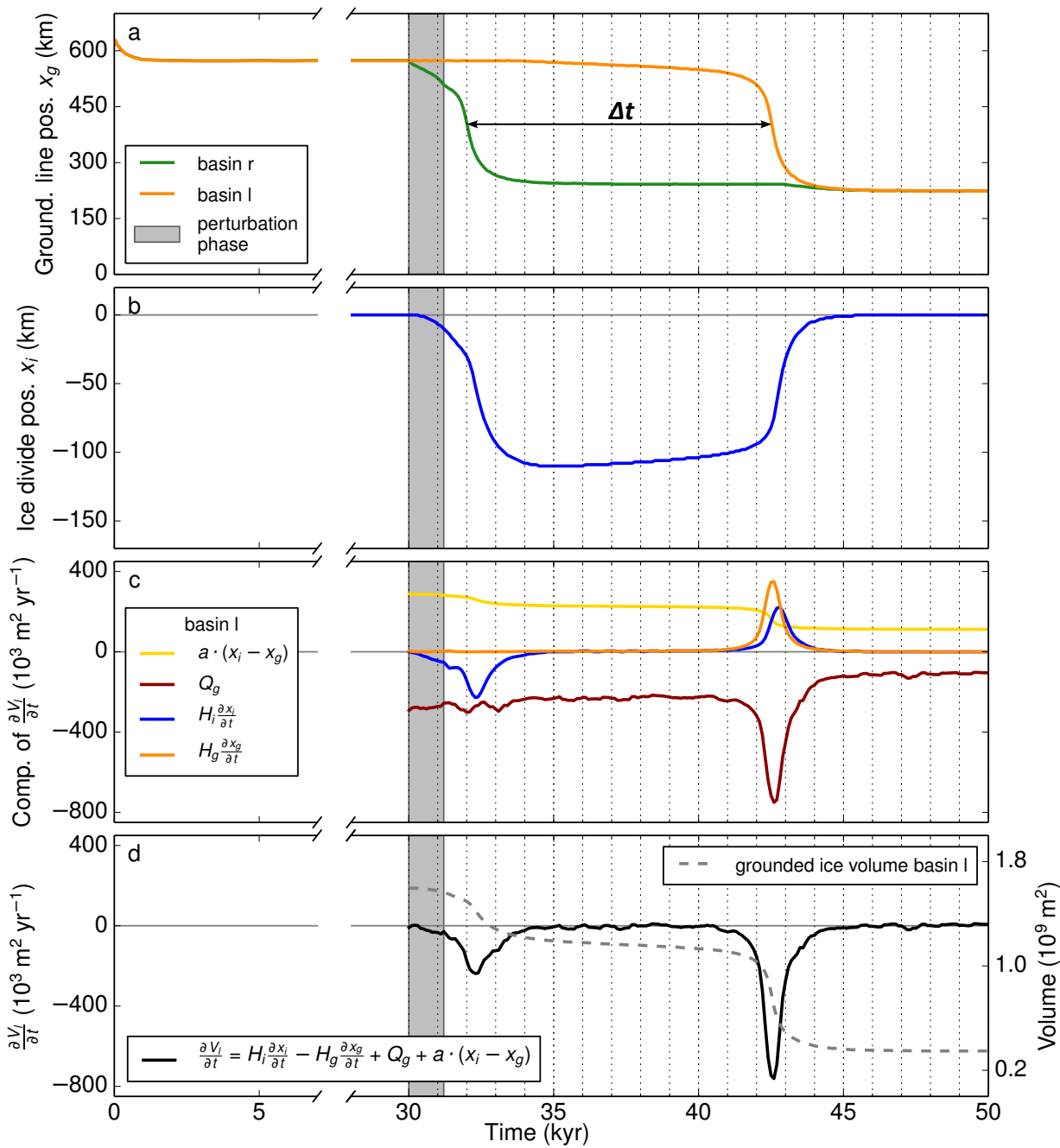

Figure 5. Time series for the unstable scenario $U$ (simulation $\mathrm{BC} 0$, see Figs. $3 \mathrm{a}$ and $4 \mathrm{a}$ ) of (a) the absolute value of the grounding line positions (b) the position of the ice divide (as defined in the text), (c) the individual components of $\frac{\partial V_{l}}{\partial t}$ (as derived in Sect. 3.1, smoothed with a 500-year moving window), (d) the sum of these components and the grounded ice volume of basin 1 . The transition time $\Delta t$, used in Eqs. (8)-(10), is depicted by a double-headed arrow in (a).

with $b_{\mathrm{c}} \geq+340 \mathrm{~m}$ the grounding line in basin 1 remains located on the oceanward side of the sill. The resulting steadystate ice sheet hence has an asymmetric shape ("stable" scenario S, Fig. 4b). Simulations using a central bed elevation of $b_{\mathrm{c}} \leq-470 \mathrm{~m}$ initially show the same process of unstable grounding-line retreat in basin 1 as in scenario U. However, in contrast to scenario $\mathrm{U}$, the grounding line in basin 1 does not stabilize and at some point a grounding-line retreat in basin $r$ sets in again. This results in a total collapse of the ice sheet ("collapsing" scenario C). We visualize the time evolution of the ice-sheet profile also in a short movie for the scenarios $U$ and $S$, respectively (see the Supplement).

Characteristic features that go along with the triggered unstable grounding-line retreat in the RHS basin $r$ are a shift of the ice-divide position (defined as the location through which there is zero ice flux) towards the LHS basin 1 (Figs. 5-7, panel b), a non-zero and increasing ice flux through $x_{\mathrm{c}}$ (from basin 1 into basin r) and a decrease in grounded ice-sheet volume. The simulations of the unstable scenario U imply a triggered MISI also in basin 1, causing the ice divide to shift back to its original position, including a further decrease in icesheet volume. Before stabilization, a slight grounding-line retreat in basin $r$ sets in again (Fig. 5a). In the stable scenario $\mathrm{S}$ the position of the ice divide, the ice flux through $x_{\mathrm{c}}$ and the ice volume adjust only slightly after the grounding line in basin $r$ has stabilized, reflecting the asymmetric shape of the resulting ice sheet (Figs. $4 \mathrm{~b}$ and 6 ). The collapsing scenario $\mathrm{C}$ is very similar to scenario $\mathrm{U}$, with the difference that in the former, the reoccurrence of grounding-line retreat in basin $\mathrm{r}$ is significantly larger, with grounded ice volume eventually dropping to zero as both grounding lines synchronously reach $x=0$ (Fig. 7). 


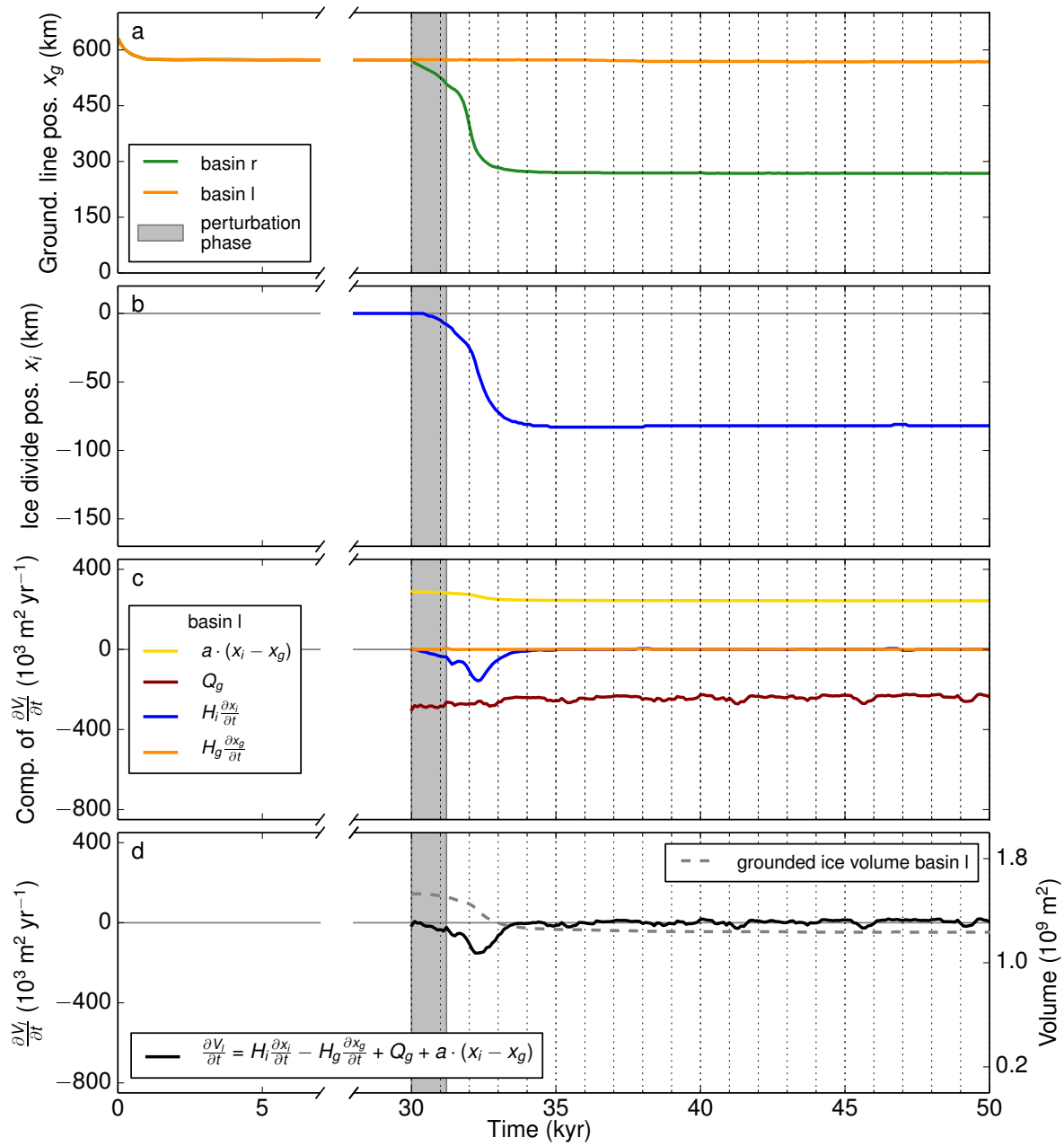

Figure 6. Same as Fig. 5 but here for the stable scenario S (simulation BC+400, see Fig. 4b).

\subsection{Conceptual analysis of interaction of instabilities}

Here, we discuss possible scenarios of basin interaction for a given bed topography $b(x)$ and surface accumulation $a$ conceptually. According to Schoof (2007a), the flux across the grounding line for the present unbuttressed SSA problem in flow line is a function of local bed topography and for our used parameters has the form of

$Q_{\mathrm{g}}(x) \sim-b(x)^{19 / 4}$.

We thus can calculate a theoretical grounding-line flux for each $x$ given a fixed bed geometry like the symmetric, overdeepened bed shape we prescribe in this study (Fig. 8a, black curve). Possible steady-state grounding-line positions exist where inflow equals outflow, i.e., where the integrated mass gain between ice divide and grounding line equals ice discharge across the grounding line, and hence are given by the intersections of the line $a x$ with $Q_{\mathrm{g}}(x)$ in Fig. 8a. In the case of a symmetric ice sheet, the same number of stable solutions exists on both sides of the ice sheet (num- ber depending on the magnitude of surface accumulation). Grounding-line positions on the retrograde bed section are unstable (Schoof, 2007a).

We now consider the case examined in our experiments: a symmetric steady-state ice sheet with grounding lines located on the ocean side of the coastal sill (Fig. 8b, gray line) is perturbed in basin $r$ such that the RHS grounding line enters the retrograde bed section. A new stable solution is found on the central landward up-sloping bed section. The corresponding leftward ice-divide shift then alters the set of possible stable grounding-line positions in basin 1 . The strength of the shift determines the extent to which the basin's area of mass gain is reduced (Fig. 8b, colored lines). For a small displacement of the ice divide (blue line) a stable grounding-line position in basin 1 still exists oceanward of the coastal sill. Basin 1 thus remains stable, and the final steady-state ice sheet is of asymmetric shape, corresponding to scenario $\mathrm{S}$ (Fig. 4b). For a moderate shift of the ice divide (red line) only one stable grounding-line solution in basin 1 remains, i.e., on the central bed section. The ice in basin 1 hence has destabilized (sce- 


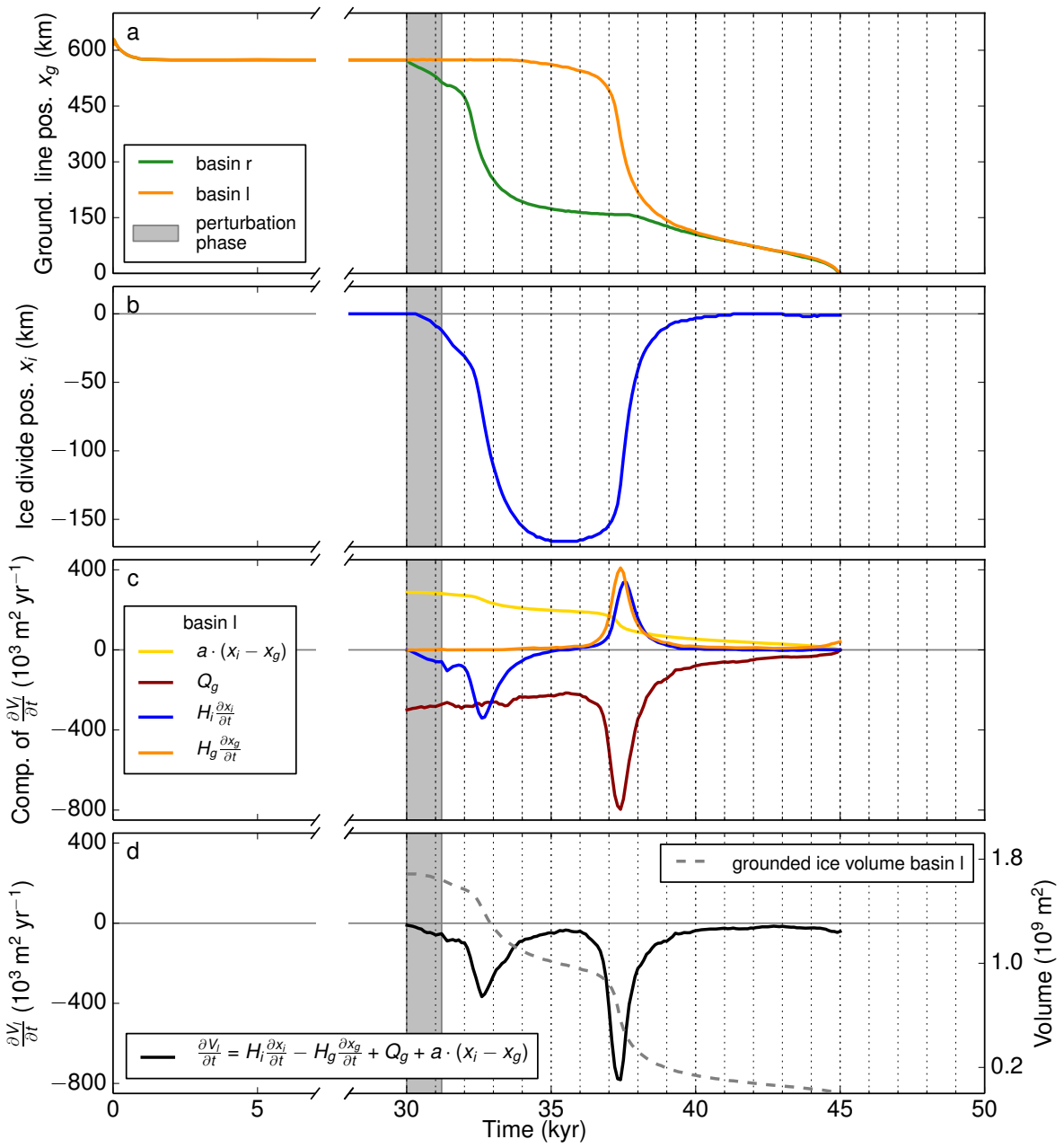

Figure 7. Same as Fig. 5 but here for the collapsing scenario C (simulation BC-500).

nario $\mathrm{U})$. The ice divide will move back to the center $(x=0)$ such that the stable solutions in basins 1 and $\mathrm{r}$ will be symmetric again (Fig. 4a). If the ice-divide shift is large (purple line) no grounding-line solution exists in basin 1 (basin collapse, scenario C).

\subsection{Basin perturbation by ice-divide migration}

The stability of the ice in basin 1 is determined by the distance that the ice divide moves towards basin 1 in response to thinning in basin $\mathrm{r}$. The shift of the ice divide depicts a perturbation to basin 1 in a way that the basin's area of mass gain through surface accumulation is reduced. The strength of this perturbation, to which ice dynamics in the basin have to adjust, decides about whether the system remains stable (scenario S) or undergoes an instability (scenarios $\mathrm{U}$ and $\mathrm{C}$ ).

The stability of the ice in basin 1 can be analyzed by considering the temporal evolution of its grounded volume, which can be written as

$$
\frac{\partial V_{1}}{\partial t}=\frac{\partial}{\partial t} \int_{x_{\mathrm{g}}(t)}^{x_{\mathrm{i}}(t)} H(x, t) \mathrm{d} x,
$$

where $H$ is the ice thickness and $x_{\mathrm{g}}$ and $x_{\mathrm{i}}$ denote the location of the grounding line and ice divide, respectively. Carrying out the Leibniz integration rule and using the ice-thickness equation, $\frac{\partial H}{\partial t}=-\frac{\partial Q}{\partial x}+a$, yields

$\frac{\partial V_{1}}{\partial t}=H_{\mathrm{i}} \frac{\partial x_{\mathrm{i}}}{\partial t}-H_{\mathrm{g}} \frac{\partial x_{\mathrm{g}}}{\partial t}+Q_{\mathrm{g}}+a \cdot\left(x_{\mathrm{i}}-x_{\mathrm{g}}\right)$,

where $H_{\mathrm{i}}$ and $H_{\mathrm{g}}$ give the ice thickness at the ice divide and the grounding line, respectively. $Q_{\mathrm{g}}$ is the ice flux across the grounding line, which is negative in basin 1 , and $a$ is the constant surface accumulation. A sufficient condition for the left basin to remain stable is that the basin does not lose ice volume $\left(\frac{\partial V_{1}}{\partial t} \geq 0\right)$. This condition is equivalent to

$H_{\mathrm{i}} \frac{\partial x_{\mathrm{i}}}{\partial t}+a \cdot\left(x_{\mathrm{i}}-x_{\mathrm{g}}\right) \geq H_{\mathrm{g}} \frac{\partial x_{\mathrm{g}}}{\partial t}-Q_{\mathrm{g}}$. 
An oceanward motion of the ice divide hence would have to be compensated by an equally directed motion of the grounding line and/or a decrease of the ice-flux magnitude across the grounding line. This is not the case for any of our investigated scenarios. Regarding scenarios $\mathrm{U}$ and $\mathrm{C}$, on the short term, the grounding-line position remains constant and $Q_{\mathrm{g}}$ increases only very slightly, approximately balancing the reduction of the basin's mass gain through surface accumulation (Fig. 5c). The decrease in basin length hence translates directly into a volume decrease of the system (Fig. 5d). The timescale of adjustment of the ice flow is much larger than the perturbation timescale and thus the grounding-line retreat sets in not before the ice divide has almost reached its maximum displacement (Fig. 5a and b). The slow retreat of the grounding line is nearly balanced by a back shift of the ice divide such that the total ice volume is close to stabilization. At the time the grounding line starts to undergo unstable retreat on the reverse bed slope, the magnitude of flux across the grounding line increases significantly, resulting in abrupt mass loss which cannot be compensated by the accelerated back shift of the ice divide. The volume starts to stabilize once the grounding-line retreat slows down and the grounding-line-flux magnitude decreases. Regarding scenario $U$, the system reaches a new equilibrium as the motion of its boundaries attenuates and grounding-line flux is again in balance with surface accumulation. In scenario C (Fig. 7) the grounding-line retreat continues and the associated reduction in basin length cannot be compensated by the decrease in flux magnitude across the grounding line, resulting in continued net grounded ice loss of basin 1 .

Regarding scenario $\mathrm{S}$, the short-term evolution of basin 1 is similar to the other two scenarios (compare Fig. 6 to Figs. 5 and 7). However, during the time of ice-flow adjustment the system equilibrates with mass gain and grounding-line flux remaining in balance. The grounding line hence stays approximately located at its original position and also the ice divide reaches a stable position. The ice-divide perturbation is not large enough to induce self-sustained grounding-line retreat and associated basin destabilization.

\subsection{Scaling of symmetric steady-state ice sheets}

For several simplified ice-sheet problems analytic solutions of steady-state ice-sheet profiles have been derived (Greve and Blatter, 2009; Bueler, 2014). Vialov (1958) derived an analytic solution for the profile of a symmetric, isothermal steady-state flow-line ice sheet for the SIA of the momentum balance, where vertical shearing is dominant. The surface elevation $h$ of the ice sheet that is grounded on a flat bed is then basically determined by its length $L$ :

$h(x)=h_{\mathrm{c}} \cdot\left[1-\left(\frac{x}{L}\right)^{(n+1) / n}\right]^{n /(2 n+2)}$ with $x \in[-L, L]$,

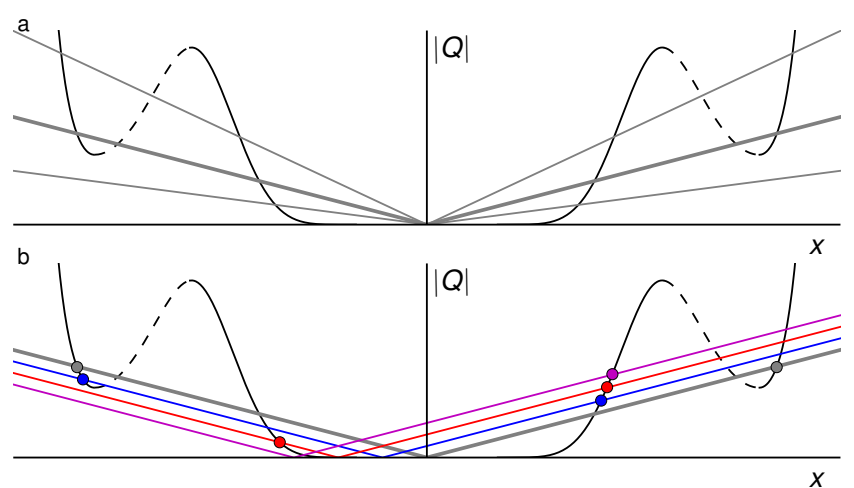

Figure 8. Conceptual picture to identify steady-state grounding line positions and analyze basin stability. The grounding-line flux $Q_{\mathrm{g}}$ (black curve) according to Eq. (1) is shown for a symmetric, overdeepened bed shape used in our experiments. The dashed lines mark the sections of retrograde bed. (a) Different gray lines show the mass gain through snowfall, $a x$, for a symmetric ice sheet for three different magnitudes of surface accumulation $a$. Intersections of $Q_{\mathrm{g}}$ and $a x$ yield possible steady-state grounding line positions. (b) Colored lines give $a\left(x-x_{\mathrm{i}}\right)$ for one accumulation magnitude (thick line in panel a) but different positions of the ice divide, $x_{\mathrm{i}}$, that is shifted leftward in response to an assumed destabilization of basin r. Grounding line positions (circles) are shown for the three scenarios S (blue), $\mathrm{U}$ (red) and C (purple) discussed in this study as well as an initial symmetric steady state (gray).

where

$h_{\mathrm{c}}=2^{n /(2 n+2)} \cdot\left(\frac{a}{A}\right)^{1 /(2 n+2)} \cdot L^{1 / 2}$

is the surface elevation at the center of the ice sheet (at the ice divide) with uniform accumulation $a$ and ice softness $A$. The equation in brackets in Eq. (5) represents the nondimensionalized universal shape of an SIA ice sheet under the above conditions.

Vialov's and our idealized cases share several assumptions but also differ substantially in some respects. In contrast to Vialov, we use a non-flat bed, allow for basal sliding and longitudinal stresses in the ice sheet are predominant over vertical shearing (the SSA velocities are large compared to the SIA velocities for the major part of the grounded ice sheet; SIA influence discussed in Appendix C), features which are typical for ice streams found in the WAIS. However, using Eq. (5) with $n=3$ and prescribing $h_{\mathrm{c}}$ and $L$ from model output, the Vialov profile (dotted lines in Fig. $3 b$ and c) resembles the profile that we obtain from our steady simulation (solid gray lines in Fig. $3 \mathrm{~b}$ and c).

For a given bed topography in our simulations of scenario $\mathrm{U}$ the initial and final symmetric steady-state profiles of the ice sheet substantially differ in size but have a similar shape. Equation (5) can be used to scale between two such ice sheets 


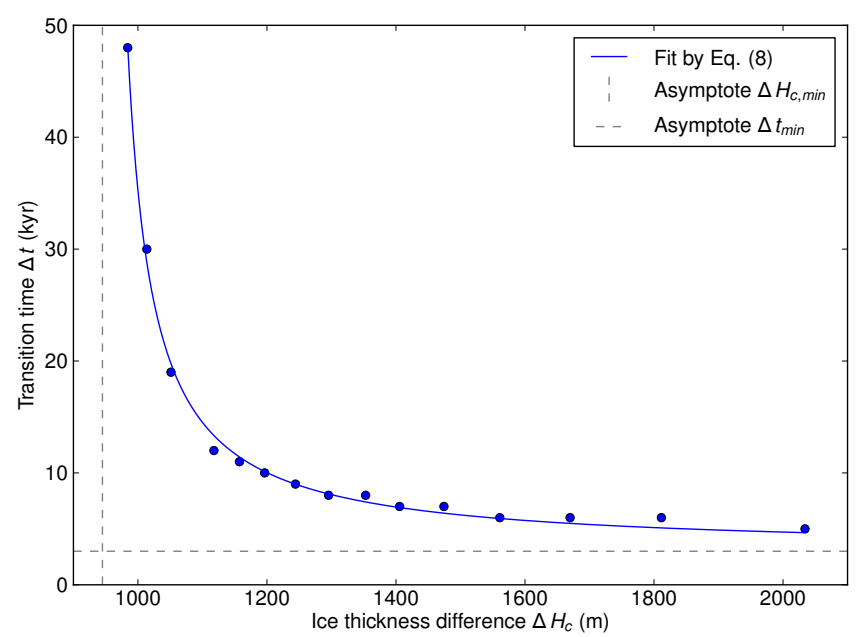

Figure 9. Transition time of MISI $\Delta t$ plotted against central ice thickness difference between initial and final steady states of the ice sheet $\Delta H_{\mathrm{c}}$. Each dot represents a simulation of scenario $\mathrm{U}$ with a different central bed elevation $b_{\mathrm{c}}$. The constants for the fit by Eq. (8) are $\Delta t_{\min }=3000 \mathrm{yr}, \Delta H_{\mathrm{c}, \min }=945 \mathrm{~m}$ and $C=1727 \mathrm{yr} \mathrm{m}$.

of lengths $L_{0}$ and $L_{1}$, respectively,

$h_{1}\left(x_{1}\right)=h_{0}(x) \cdot\left(\frac{L_{1}}{L_{0}}\right)^{1 / 2}$,

where $x_{1}=x \cdot \frac{L_{1}}{L_{0}}$ with $x \in\left[-L_{0}, L_{0}\right]$,

using the same scaling exponent of $1 / 2$ as derived for the central ice thickness of the Vialov profile. We apply the above scaling using the initial surface elevation $h_{0}$ as well as the initial and final grounding-line positions from model output to arrive at the final surface elevation $h_{1}$ (shown exemplary for two different central ridge elevations as dashed lines in Fig. $3 \mathrm{~b}$ and c). That is to say, the simulated ice sheet exhibits more or less the same relation between its central ice thickness and its horizontal extent.

\subsection{Scaling of transition time between instabilities}

In the unstable scenario U two MISIs succeed each other. The first MISI in the RHS basin $r$ (which was previously triggered by a local perturbation) causes the initiation of a second MISI in the connected LHS basin 1, a process going on only due to internal ice-sheet dynamics. The transition time $\Delta t$ between the occurrence of both events of unstable grounding-line retreat (Fig. 5a) ranges from several kyr to $10 \mathrm{kyr}$ and is practically independent of the initial trigger. Assuming that the difference between the ice thickness of the two states is the internal force for the transition, we scale $\Delta t$ with $\Delta H_{\mathrm{c}}=\left(h_{1}-h_{0}\right)(x=0)$, i.e., the central ice thickness difference between the final and initial steady-states of the ice sheet (Fig. 3a). The relation

$\Delta t=\Delta t_{\min }+C \cdot\left(\Delta H_{\mathrm{c}}-\Delta H_{\mathrm{c}, \min }\right)^{-1}$

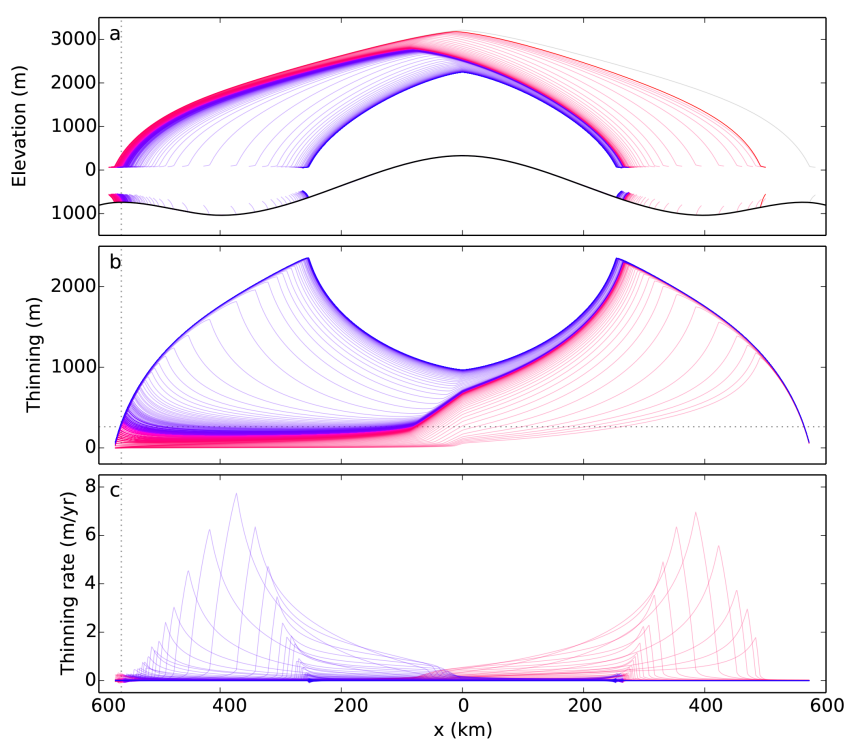

Figure 10. Ice-sheet (a) profile, (b) thinning with respect to the ice thickness at the end of perturbation and (c) thinning rate at multiple stages (time interval 100 years) of the unstable scenario U (simulation $\mathrm{BC}+330$ ). The ice shelf is truncated for better visibility. The vertical dotted line indicates the location of maximum sill elevation $x_{-s}$. The horizontal dotted line in panel (b) gives the amount of cumulative thinning necessary to cause the ice situated on the local bed maximum to become afloat. The same color-coding as in Fig. 4 applies.

provides a good approximation of the transition time with constants $C, \Delta t_{\min }$ and $\Delta H_{\mathrm{c}, \min }$ (Fig. 9). Here $\Delta t_{\min }$ and $\Delta H_{\mathrm{c}, \min }$ have clear physical interpretations and represent a minimum transition time and a minimum ice thickness difference, respectively. These asymptotes constrain the regime for which the MISI in basin 1 is triggered, and the final steady-state ice sheet is of symmetric shape (scenario U): for $\Delta H_{\mathrm{c}}<\Delta H_{\mathrm{c}, \min }$, the ice sheet remains asymmetric (scenario $\mathrm{S})$, whereas in the regime $\Delta t<\Delta t_{\min }$ it collapses completely (scenario C).

Replacing $\Delta H_{\mathrm{c}}$ with the above definition and using Eq. (7), the transition time (Eq. 8) can be rewritten as

$\Delta t=\Delta t_{\min }+C \cdot\left(h_{0, \mathrm{c}} \cdot\left[\left(\frac{L_{1}}{L_{0}}\right)^{1 / 2}-1\right]-\Delta H_{\mathrm{c}, \min }\right)^{-1}$,

which allows a scaling of the transition time based on the initial central surface elevation of the ice sheet, $h_{0, \mathrm{c}}$, and Vialov's $L^{1 / 2}$ dependency.

The transition time can also be expressed in terms of the grounding-line shift between the ice sheet's two steadystates: $\Delta L=L_{0}-L_{1}$. Since $\Delta L$ is approximately a linear function of the central ice thickness difference $\Delta H_{\mathrm{c}}$, Eq. (8) can also be written as

$\Delta t=\Delta t_{\min }+D \cdot\left(\Delta L-\Delta L_{\min }\right)^{-1}$ 


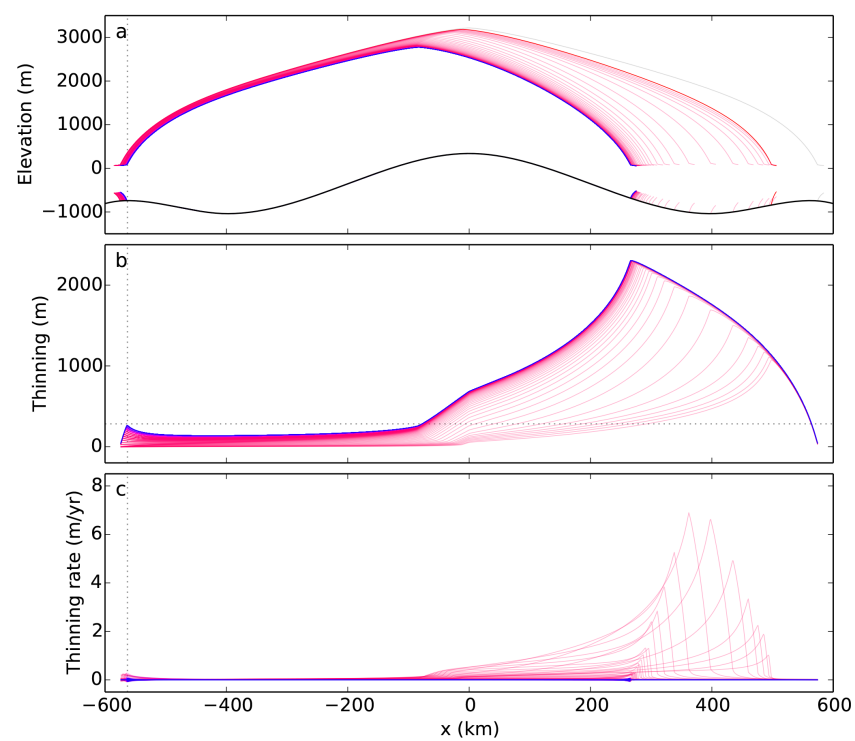

Figure 11. Same as Fig. 10 but here for the stable scenario S (simulation $\mathrm{BC}+340)$.

by using a different coefficient $D$ instead of $C$. The threshold $\Delta H_{\mathrm{c}, \text { min }}$ is replaced by a threshold of a minimum groundingline retreat, $\Delta L_{\min }$, which has to be exceeded to enable the MISI initiation in basin 1 .

\subsection{Transient dynamic thinning and basin stability}

Here we describe the temporal evolution of the ice sheet after cessation of its perturbation in detail. We reveal the origin of the qualitative difference between the unstable/collapsing scenarios U/C, which imply a MISI transition between basin 1 and $r$, and the stable scenario $S$, which does not imply such a transition. The grounding-line retreat in the RHS basin $r$, which continues after the perturbation, is associated with a dynamic thinning of the upstream ice (Figs. 10 and 11). The thinning declines with increasing distance from the grounding line towards the interior of the domain but is still nonzero in the center of the ice sheet and reaches further into the LHS basin 1 with time. While the grounding line stabilizes in basin $r$ and the local thinning rate goes to zero, the inland thinning propagates far enough into basin 1 to reach the local grounding line. Here the increasing thinning rate eventually results in a grounding-line retreat. Depending on the scenario, the thinning in basin 1 then continues to propagate back into the interior of the basin (scenarios $\mathrm{U}$ and $\mathrm{C}$, instability in basin 1 triggered) or ceases (scenario $\mathrm{S}$, instability not triggered).

We compare the time evolution of the ice in basin 1 for two simulations which show this qualitative difference in stability while having almost the same bed topography (simulations $\mathrm{BC}+330$ and $\mathrm{BC}+340$ ). In simulation $\mathrm{BC}+330$, the grounding line in basin 1 retreats beyond the point of maximum sill elevation. The thinning continues to propagate into the in- terior and the thinning rate increases during the grounding line's unstable retreat on the retrograde section of the bed. Temporarily, basin $r$ is now affected by an inland thinning, which results in a slight retreat of the previously stabilized grounding line in basin $r$ (Fig. 10). The rate of the thinning in both basins goes to zero as the grounding lines find their steady-state position synchronously. In simulation BC +340 , the thinning rate in basin 1 goes to zero as the grounding line migrates upstream towards the point of local maximum bed elevation (Fig. 11c). The cumulative thinning there (at the tip of the sill) is insufficient to cause the ice to become afloat (indicated by dotted cross in Fig. 11b). Due to the almost identical setups of both simulations we identify the location of maximum elevation of the sill in basin 1 as the instability threshold; i.e., a grounding-line retreat beyond this point implies the initiation of a MISI in basin 1 .

\section{Discussion and conclusions}

We investigate the possibility of whether a MISI can be triggered from the direction of the ice divide as opposed to coastal forcing and to this end study the interaction between connected basins. In our experiments we perturb one basin to analyze its interaction with a connected basin. The extent of grounding-line retreat in the aftermath of the triggered MISI in the perturbed basin significantly determines the degree of interaction with the other basin, including a scenario of an induced MISI (scenarios U and C). Our results can also be interpreted such that the motion of the ice divide that is induced by the destabilization of one basin imparts a perturbation to the connected basin. The magnitude of the ice-divide shift decides about the stability of the connected basin. This not only comes out of our results from simulation but can also be explained by means of a conceptual flux-balance analysis in steady state (Fig. 8).

The transition of the MISI between the two basins takes place without external forcing and hence only due to internal ice-sheet dynamics. This feature is robust against a reduction in surface accumulation (simulations using an accumulation rate 1 order of magnitude lower demonstrate the same quality like the runs shown here). Our results are also independent of the selected perturbation (see Appendix A and Fig. A1). In most of our experiments, grounding-line retreat is forced by ocean melting that is also applied (in a reduced way) to grounded grid cells below sea level adjacent to a floating grid cell. This way, an extra flux out of these coastal grid cells is produced that qualitatively resembles the response of an ice sheet to a reduction in ice-shelf buttressing. Such imposed resolution-dependent flux increase has to be handled with care due to the possibility of overriding actual ice dynamics. However, since we use such melting only to force grounding-line retreat until a certain point, stopping it afterwards, the MISI process and the mechanism of basin inter- 
action revealed in this study are left unaffected by the perturbation method.

While the unstable grounding-line retreat in our experiments is in accordance with findings by Schoof (2007a), the possibility of a MISI in three dimensions highly depends on the geometry of the ice sheet and the underlying bed (Joughin et al., 2010; Katz and Worster, 2010; Gudmundsson, 2013; Parizek et al., 2013; Mengel and Levermann, 2014; Joughin et al., 2014). The timescales of ice-sheet response in our experiments are on the order of magnitude of $1 \mathrm{kyr}$ (unstable grounding-line retreat) to $10 \mathrm{kyr}$ (transition time between MISIs in basin 1 and $r$ ). The stabilizing effect of buttressing in three dimensions would most probably slow down basin interaction.

On the timescales discussed here, the influence of glacial isostatic adjustment (Peltier, 2004; Bueler et al., 2007), which for simplicity is not included in our study, might become relevant. In response to ice thinning and groundingline retreat, an asymmetrical bed deformation with feedback on grounding-line motion has to be expected, including the possibility of an earlier grounding-line stabilization in basin $r$ than in the static-bed case. However, the three scenarios investigated in our study are expected to remain valid in the dynamic-bed case since each scenario exists for a broad range of central bed elevations, though the thresholds between the scenarios presumably would shift.

The underlying mechanism of basin interaction in our simulations is based on a dynamic thinning of the ice (Fig. 4). Originating in one basin and reaching as far as to the grounding line of the other basin, it enables far field communication between the grounding lines of both basins (Figs. 10 and 11). Dynamic thinning is of course not limited to two dimensions. However, in three dimensions it might propagate less straight away from the grounding line but also spread laterally. Nevertheless, a possible influence of future thinning in the basins of the Amundsen Sea sector onto other basins in the WAIS, e.g., extensive thinning of PIG affecting FRIS basin, cannot be excluded.
Based on the Vialov profile (Eq. 5) we do a simple scaling of the initial and final symmetric steady-state surface elevations of the grounded ice sheet for the unstable scenario U. The Vialov profile was derived using several assumptions which do not apply to our setup. In particular it is an SIA solution for a flat, non-sliding bed, while our simulations are SSA-dominated, our bed topography is non-trivial, and we allow for basal sliding. Given these substantial differences, the ice-sheet profiles from Vialov's equation and from our model results are in good agreement, and also the scaling of steady-state surface elevations via Eq. (7) works reasonably well.

The elevation of the central bed ridge in our setup has a strong influence on the steady-state grounding-line position in the RHS basin $r$ (Fig. 3). With increasing elevation of the central ridge the grounding line stabilizes farther from the center with the result that far field thinning in the LHS basin 1 becomes weaker and thus takes longer to affect the grounding line in basin 1 (Fig. 9). This is also made apparent by Eq. (10), which states that the transition time scales inversely with the extent of grounding-line retreat and includes a threshold of a minimum grounding-line retreat below which basin 1 remains stable. The central ridge may hence be considered as a barrier which can dampen/facilitate basin interaction when being elevated/lowered. In other words, grounding-line retreat in the perturbed basin strongly determines the degree and the quality of the interaction with the connected basin. 


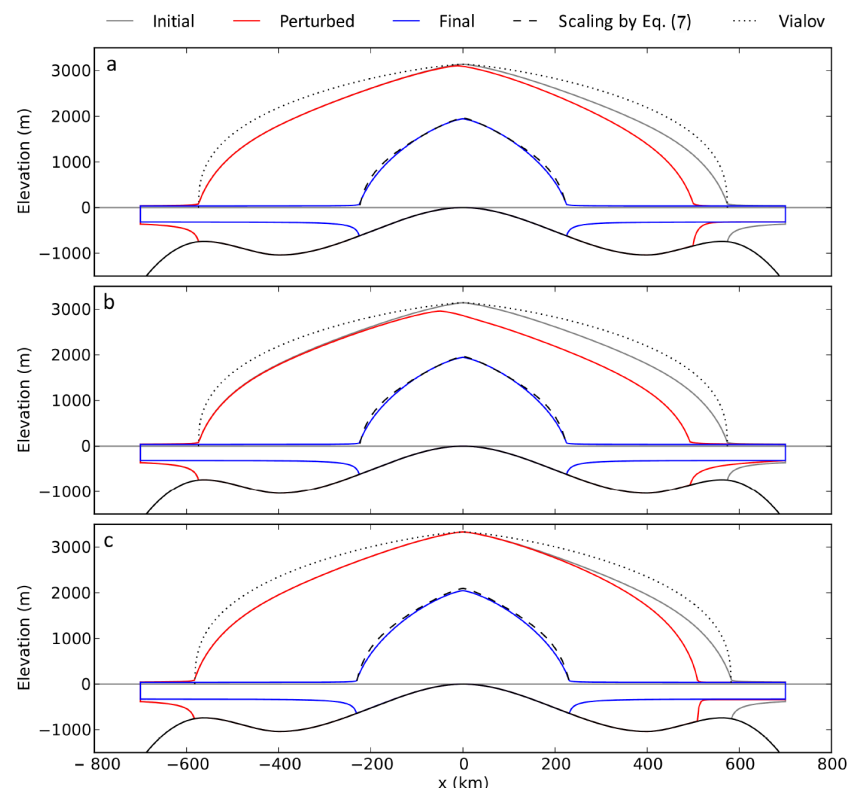

Figure A1. Ice-sheet profiles at three stages of simulation for a central bed elevation of $b_{\mathrm{c}}=0 \mathrm{~m}$ with applied (a) oceanic (same as Fig. 3a) and (b) atmospheric perturbation. Panel (c) shows a set of SSA only simulations using an oceanic perturbation.

\section{Appendix A: Applying an alternative perturbation in basin $\mathbf{r}$}

We apply a different type of perturbation to show that the mechanism of MISI interaction revealed in our study does not depend on the particular way the destabilization of basin $r$ is triggered. The set of experiments is carried out as described in Sect. 2 with the exception that during the perturbation phase the ocean forcing is replaced by an atmospheric one. Ocean melting hence remains zero throughout the whole sequence of experiments. Instead, the surface accumulation $a$ is set zero for $x>0$ (basin $r$ in steady state) and for the rest of the domain $a$ remains at its original value. The perturbation length is the same as for the ocean-forced simulations (1.3 kyr).

Figure A1a and b show that similar destabilization takes place in basin 1 in response to either the atmospheric or oceanic perturbation in basin $r$. The ice-sheet profiles differ only at the end of the perturbation phase (red profiles). The atmospheric perturbation causes large-scale ice thinning in basin $r$ associated with an ice-divide shift that is much larger compared to the more localized oceanic perturbation. However, the steady-state profiles that result after the destabilization of basin 1 are quasi-identical. It is hence not decisive by which kind of forcing but that the MISI in basin $r$ is triggered.
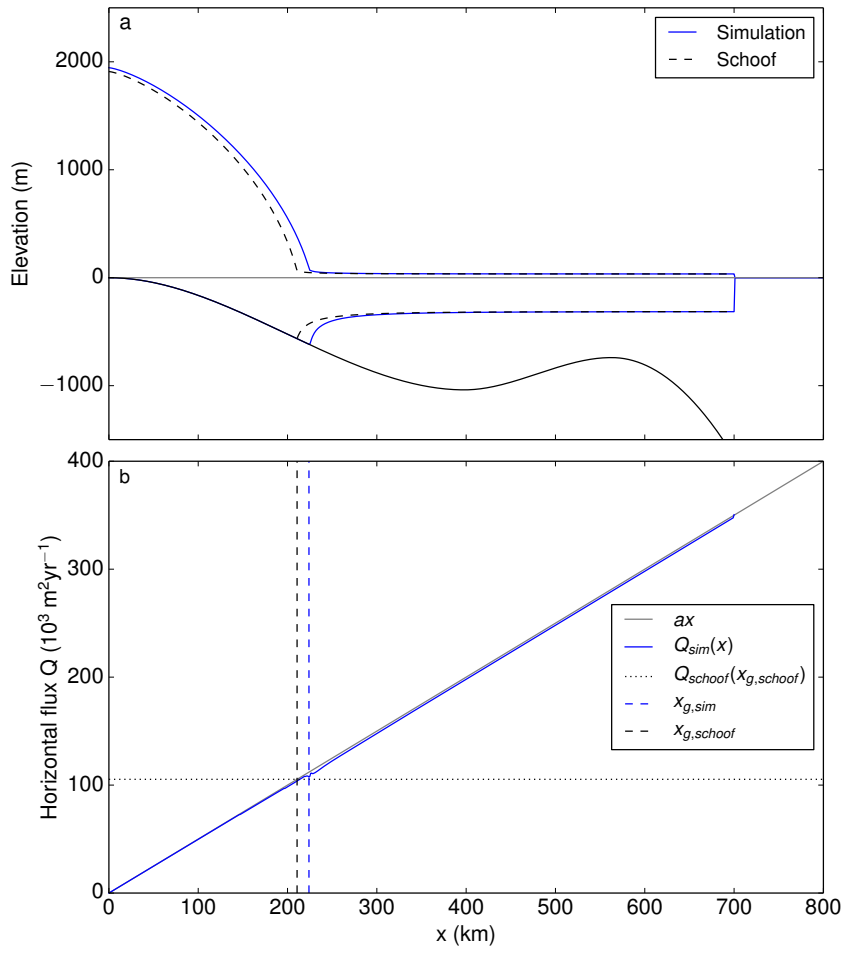

Figure A2. (a) Comparison between the semi-analytical ice-sheet profile from Schoof and our modeling result for the final steadystate ice sheet of simulation BC0 (only the RHS of the symmetric ice sheet is shown here). Panel (b) shows Schoof's and the modeled grounding line position, $x_{\mathrm{g}, \text { schoof }}=211 \mathrm{~km}$ and $x_{\mathrm{g}, \mathrm{sim}}=224 \mathrm{~km}$, respectively, as well as the steady-state ice flux from simulation, $Q_{\text {sim }}(x)$, along the model domain to compare with ax and the analytically derived Schoof flux, $Q_{\mathrm{g}}$, at $x_{\mathrm{g} \text {, schoof }}$.

\section{Appendix B: Comparison to Schoof's solution from boundary layer theory}

We here compare our modeled steady-state ice-sheet profile to the solution derived from boundary layer theory (Schoof, 2007a, b). Schoof's grounding-line position and the corresponding ice-sheet profile are obtained by finding the roots of Eq. (22) with Newton's method and subsequent integration of Eq. (25), both in Schoof (2007a), using the parameters of our setup. The solution is complemented by the profile for an ice shelf in equilibrium (Van der Veen, 2013).

The modeled ice-sheet profile is similar to the semianalytical profile but has a downstream offset of the grounding-line position (Fig. A2a). The difference in grounding-line position might be explained by the dip in ice flux at the grounding line in our simulations (Fig. A2b). A larger grounding-line flux would cause upstream ice thinning and hence result in a grounding-line location that is closer to the theoretical solution. Part of the difference in groundingline position might also be explained by the finite horizontal grid resolution of $1 \mathrm{~km}$ used in our simulations. 


\section{Appendix C: Influence of SIA in our simulations}

To test the influence of the SIA in our hybrid SSA+SIA simulations (see Sect. 2) we additionally carry out simulations that only account for the SSA. We find that the mechanism of MISI interaction still exists in the SSA-only case, i.e., in the absence of vertical shearing.

During spin-up under SSA-only conditions the symmetric grounding lines migrate further upstream than in the SSA+SIA case which can be explained by the lack of horizontal ice diffusion. The grounding lines enter the retrograde bed section and equilibrate at the flank of the central ridge. To achieve an equilibrium ice sheet with stable grounding lines that are located on the oceanward sides of the coastal sills (as in the SSA+SIA case), we apply an increased rate of surface accumulation. Carrying out the whole sequence of experiments in this modified setup reveals that the mechanism of MISI interaction is also present in the SSA-only case (exemplary shown in Fig. A1c). In comparison to the SSA+SIA simulations the ice sheet is thicker, which is a direct effect of the applied increased surface accumulation. However, the ice-sheet profiles are very similar (compare Fig. A1a and c), which confirms that the SSA plays the dominant role in our simulations. 


\section{The Supplement related to this article is available online at doi:10.5194/tc-9-631-2015-supplement.}

Acknowledgements. We would like to thank Stephen Cornford for extremely helpful comments during the review process and also two anonymous reviewers for their detailed comments which helped to improve the paper. The research leading to these results has received funding from the European Union Seventh Framework Programme FP7/2007-2013 under grant agreement no. 603864. J. Feldmann is funded by Deutsche Bundesstiftung Umwelt.

Edited by: F. Pattyn

\section{References}

Anandakrishnan, S., Alley, R. B., and Waddington, E. D.: Sensitivity of the ice-divide position in Greenland to climate change, Geophys. Res. Lett., 21, 441-444, doi:10.1029/94GL00094, 1994.

Beckmann, A. and Goosse, H.: A parameterization of ice shelfocean interaction for climate models, Ocean Model., 5, 157-170, doi:10.1016/S1463-5003(02)00019-7, 2003.

Bindschadler, R. A., Nowicki, S., Abe-ouchi, A., Aschwanden, A., Choi, H., Fastook, J., Granzow, G., Greve, R., Gutowski, G., Herzfeld, U., Jackson, C., Johnson, J., Khroulev, C., Levermann, A., Lipscomb, W. H., Martin, M. A., Morlighem, M., Parizek, B. R., Pollard, D., Price, S. F., Ren, D., Saito, F., Sato, T., Seddik, H., Seroussi, H., Takahashi, K., Walker, R., and Wang, W. L.: Ice-sheet model sensitivities to environmental forcing and their use in projecting future sea level (the SeaRISE project), J. Glaciol., 59, 195-224, doi:10.3189/2013JoG12J125, 2013.

Bueler, E.: An exact solution for a steady, flow-line marine ice sheet, J. Glaciol., 60, 1117-1125, doi:10.3189/2014JoG14J066, 2014.

Bueler, E. and Brown, J.: Shallow shelf approximation as a "sliding law" in a thermomechanically coupled ice sheet model, J. Geophys. Res., 114, 1-21, doi:10.1029/2008JF001179, 2009.

Bueler, E., Lingle, C. S., and Brown, J.: Fast computation of a viscoelastic deformable Earth model for ice sheet simulation, Ann. Glaciol., 46, 97-105, 2007.

Cuffey, K. M. and Clow, G. D.: Temperature, accumulation, and ice sheet elevation in central Greenland through the last deglacial transition, J. Geophys. Res., 102, 26383-26396, doi:10.1029/96JC03981, 1997.

Favier, L., Durand, G., Cornford, S. L., Gudmundsson, G. H., Gagliardini, O., Gillet-Chaulet, F., Zwinger, T., Payne, A. J., and Le Brocq, A. M.: Retreat of Pine Island Glacier controlled by marine ice-sheet instability, Nature Clim. Change, 5, 1-5, doi:10.1038/nclimate2094, 2014.

Feldmann, J., Albrecht, T., Khroulev, C., Pattyn, F., and Levermann, A.: Resolution-dependent performance of grounding line motion in a shallow model compared with a full-Stokes model according to the MISMIP3d intercomparison, J. Glaciol., 60, 353-360, doi:10.3189/2014JoG13J093, 2014.
Gagliardini, O., Durand, G., Zwinger, T., Hindmarsh, R. C. A., and Le Meur, E.: Coupling of ice-shelf melting and buttressing is a key process in ice-sheets dynamics, Geophys. Res. Lett., 37, L14501, doi:10.1029/2010GL043334, 2010.

Gladstone, R. M., Payne, A. J., and Cornford, S. L.: Parameterising the grounding line in flow-line ice sheet models, The Cryosphere, 4, 605-619, doi:10.5194/tc-4-605-2010, 2010.

Goldberg, D., Holland, D. M., and Schoof, C.: Grounding line movement and ice shelf buttressing in marine ice sheets, J. Geophys. Res., 114, F04026, doi:10.1029/2008JF001227, 2009.

Greve, R. and Blatter, H.: Dynamics of ice sheets and glaciers, Chapter no. 1, in: Advances in Geophysical and Environmental Mechanics and Mathematics, Springer, Berlin, Heidelberg, 8490, doi:10.1007/978-3-642-03415-2, 2009.

Gudmundsson, G. H.: Ice-shelf buttressing and the stability of marine ice sheets, The Cryosphere, 7, 647-655, doi:10.5194/tc-7647-2013, 2013.

Gudmundsson, G. H., Krug, J., Durand, G., Favier, L., and Gagliardini, O.: The stability of grounding lines on retrograde slopes, The Cryosphere, 6, 1497-1505, doi:10.5194/tc-6-1497-2012, 2012.

Holt, J. W., Blankenship, D. D., Morse, D. L., Young, D. A., Peters, M. E., Kempf, S. D., Richter, T. G., Vaughan, D. G., and Corr, H. F. J.: New boundary conditions for the West Antarctic ice sheet: subglacial topography of the Thwaites and Smith glacier catchments, Geophys. Res. Lett., 33, L09502, doi:10.1029/2005GL025561, 2006.

Jacobs, S. S., Jenkins, A., Giulivi, C. F., and Dutrieux, P.: Stronger ocean circulation and increased melting under Pine Island Glacier ice shelf, Nat. Geosci., 4, 519-523, doi:10.1038/ngeo1188, 2011.

Joughin, I. and Alley, R. B.: Stability of the West Antarctic ice sheet in a warming world, Nat. Geosci., 4, 506-513, doi:10.1038/ngeo1194, 2011.

Joughin, I., Smith, B. E., and Holland, D. M.: Sensitivity of 21st century sea level to ocean-induced thinning of Pine Island Glacier, Antarctica, Geophys. Res. Lett., 37, L20502, doi:10.1029/2010GL044819, 2010.

Joughin, I., Smith, B. E., and Medley, B.: Marine ice sheet collapse potentially under way for the Thwaites Glacier Basin, West Antarctica, Science, 344, 735-738, doi:10.1126/science.1249055, 2014.

Katz, R. F. and Worster, M. G.: Stability of ice-sheet grounding lines, P. Roy. Soc. A-Math. Phy., 466, 1597-1620, doi:10.1098/rspa.2009.0434, 2010.

Martin, M. A., Winkelmann, R., Haseloff, M., Albrecht, T., Bueler, E., Khroulev, C., and Levermann, A.: The Potsdam Parallel Ice Sheet Model (PISM-PIK) - Part 2: Dynamic equilibrium simulation of the Antarctic ice sheet, The Cryosphere, 5, 727740, doi:10.5194/tc-5-727-2011, 2011.

Medley, B., Joughin, I., Smith, B. E., Das, S. B., Steig, E. J., Conway, H., Gogineni, S., Lewis, C., Criscitiello, A. S., McConnell, J. R., van den Broeke, M. R., Lenaerts, J. T. M., Bromwich, D. H., Nicolas, J. P., and Leuschen, C.: Constraining the recent mass balance of Pine Island and Thwaites glaciers, West Antarctica, with airborne observations of snow accumulation, The Cryosphere, 8, 1375-1392, doi:10.5194/tc-8-13752014, 2014. 
Mengel, M. and Levermann, A.: Ice plug prevents irreversible discharge from East Antarctica, Nature Clim. Change, 4, 451-455, doi:10.1038/NCLIMATE2226, 2014.

Mercer, J. H.: West Antarctic ice sheet and $\mathrm{CO}_{2}$ greenhouse effect: a threat of disaster, Nature, 271, 321-325, 1978.

Mouginot, J., Rignot, E., and Scheuchl, B.: Sustained increase in ice discharge from the Amundsen Sea Embayment, West Antarctica, from 1973 to 2013, Geophys. Res., 41, 1576-1584, doi:10.1002/2013GL059069, 2014.

Nereson, N. and Raymond, C.: The elevation history of ice streams and the spatial accumulation pattern along the Siple Coast of West Antarctica inferred from ground-based radar data from three inter-ice-stream ridges, J. Glaciol., 47, 303-313, doi:10.3189/172756501781832197, 2001.

Nereson, N., Hindmarsh, R., and Raymond, C.: Sensitivity of the divide position at Siple Dotne, West Antarctica, to boundary forcing, Ann. Glaciol., 27, 207-214, 1998.

Parizek, B. R., Christianson, K., Anandakrishnan, S., Alley, R. B., Walker, R. T., Edwards, R. A., Wolfe, D. S., Bertini, G. T., Rinehart, S. K., Bindschadler, R. A., and Nowicki, S. M. J.: Dynamic (in)stability of Thwaites Glacier, West Antarctica, J. Geophys. Res.-Earth, 118, 638-655, doi:10.1002/jgrf.20044, 2013.

Park, J. W., Gourmelen, N., Shepherd, A., Kim, S. W., Vaughan, D. G., and Wingham, D. J.: Sustained retreat of the Pine Island Glacier, Geophys. Res. Lett., 40, 2137-2142, doi:10.1002/grl.50379, 2013.

Pattyn, F., Huyghe, A., De Brabander, S., and De Smedt, B.: Role of transition zones in marine ice sheet dynamics, J. Geophys. Res., 111, F02004, doi:10.1029/2005JF000394, 2006.

Pattyn, F., Schoof, C., Perichon, L., Hindmarsh, R. C. A., Bueler, E., de Fleurian, B., Durand, G., Gagliardini, O., Gladstone, R., Goldberg, D., Gudmundsson, G. H., Huybrechts, P., Lee, V., Nick, F. M., Payne, A. J., Pollard, D., Rybak, O., Saito, F., and Vieli, A.: Results of the Marine Ice Sheet Model Intercomparison Project, MISMIP, The Cryosphere, 6, 573-588, doi:10.5194/tc6-573-2012, 2012.

Pattyn, F., Perichon, L., Durand, G., Favier, L., Gagliardini, O., Hindmarsh, R. C., Zwinger, T., Albrecht, T., Cornford, S., Docquier, D., Fürst, J. J., Goldberg, D., Gudmundsson, G. H., Humbert, A., Hütten, M., Huybrechts, P., Jouvet, G., Kleiner, T., Larour, E., Martin, D., Morlighem, M., Payne, A. J., Pollard, D., Rückamp, M., Rybak, O., Seroussi, H., Thoma, M., and Wilkens, N.: Grounding-line migration in plan-view marine icesheet models: results of the ice2sea MISMIP3d intercomparison, J. Glaciol., 59, 410-422, doi:10.3189/2013JoG12J129, 2013.

Peltier, W.: Global glacial isostacy and the surface of the ice-age Earth: The ICE-5G (VM2) Model and GRACE, Annu. Rev. Earth Pl. Sc., 32, 111-149, doi:10.1146/annurev.earth.32.082503.144359, 2004.

Pritchard, H. D., Ligtenberg, S. R. M., Fricker, H. A., Vaughan, D. G., van den Broeke, M. R., and Padman, L.: Antarctic ice-sheet loss driven by basal melting of ice shelves, Nature, 484, 502-505, doi:10.1038/nature10968, 2012.
Rignot, E. and Mouginot, J.: Widespread, rapid grounding line retreat of Pine Island, Thwaites, Smith, and Kohler glaciers, West Antarctica, from 1992 to 2011, Geophys. Res. Lett., 41, 35023509, doi:10.1002/2014GL060140, 2014.

Rignot, E., Bamber, J. L., den Broeke, M. R. V., Li, Y., Davis, C., de Berg, W. J. V., and Meijgaard, E.: Recent Antarctic ice mass loss from radar interferometry and regional climate modelling, Nat. Geosci., 1, 106-110, 2008.

Rignot, E., Jacobs, S., Mouginot, J., and Scheuchl, B.: Iceshelf melting around Antarctica, Science, 341, 266-270, doi:10.1126/science.1235798, 2013.

Schoof, C.: Ice sheet grounding line dynamics: Steady states, stability, and hysteresis, J. Geophys. Res., 112, F03S28, doi:10.1029/2006JF000664, 2007a.

Schoof, C.: Marine ice-sheet dynamics. Part 1. The case of rapid sliding, J. Fluid Mech., 573, 27-55, 2007b.

Shepherd, A., Wingham, D. J., and Mansley, J. A. D.: Inland thinning of the Amundsen Sea sector, West Antarctica, October, 29, 7-10, 2002.

Stuiver, M., Denton, G. H., Hughes, T. J., and Fastook, J. L.: History of the Marine Ice Sheet in West Antarctica During the Last Glaciation: a Working Hypothesis, in: The Last Great Ice Sheets, edited by: Denton, G. H. and Hughes, T. J., 319-436, John Wiley and Sons, New York, 1981.

Tinto, K. J. and Bell, R. E.: Progressive unpinning of Thwaites Glacier from newly identified offshore ridge: constraints from aerogravity, Geophys. Res. Lett., 38, 1-6, doi:10.1029/2011GL049026, 2011.

Van der Veen, C. J.: Fundamentals of glacier dynamics, 2nd edition, CRC Press, Boca Raton, FL, 131-134, 2013.

Vaughan, D. G., Corr, H. F. J., Ferraccioli, F., Frearson, N., O'Hare, A., Mach, D., Holt, J. W., Blankenship, D. D., Morse, D. L., and Young, D. A.: New boundary conditions for the West Antarctic ice sheet: subglacial topography beneath Pine Island Glacier, Geophys. Res. Lett., 33, L09501, doi:10.1029/2005GL025588, 2006.

Vialov, S. S.: Regularities of glacial shields movement and the theory of plastic viscous flow, Physics of the Movements of Ice IAHS, 47, 266-275, 1958.

Walker, D. P., Brandon, M. A., Jenkins, A., Allen, J. T., Dowdeswell, J. A., and Evans, J.: Oceanic heat transport onto the Amundsen Sea shelf through a submarine glacial trough, Geophys. Res. Lett., 34, L02602, doi:10.1029/2006GL028154, 2007.

Winkelmann, R., Martin, M. A., Haseloff, M., Albrecht, T., Bueler, E., Khroulev, C., and Levermann, A.: The Potsdam Parallel Ice Sheet Model (PISM-PIK) - Part 1: Model description, The Cryosphere, 5, 715-726, doi:10.5194/tc-5-715-2011, 2011. 